\title{
Pala (Myristica fragrans Houtt) sebagai bioreaktor hayati senyawa fenilpropanoid: suatu kajian pustaka
}

\author{
Pala (Myristica fragrans Houtt) as a bioreactor of biological fenilpropanoid compounds: \\ a literature review
}

\author{
Angreni Beaktris Liunokas ${ }^{1 *}$, Ferry Fredy Karwur ${ }^{2}$ \\ 1) Magister Biologi, UniversitasKristen Satya Wacana, Salatiga, Jawa Tengah \\ ${ }^{2)}$ Fakultas Kedokteran dan Ilmu Kesehatan, Universitas Kristen Satya Wacana Salatiga, Jawa Tengah \\ *Email: liunokasrenni@gmail.com
}

Diterima 29 Juli $2019 \quad$ Disetujui 5 Oktober 2020

\section{INTISARI}

Pala (Myristica fragrans Houtt) sebagai bioreaktor hayati menghasilkan produk utama minyak asiri bernilai ekonomi tinggi, yang tersebar pada bagian-bagian buahnya. Minyak asiri pala tersusun oleh kelompok besar terpenoid dan fenilpropanoid yang memiliki konsentrasi terkecil namun sebagai indikator mutu minyak pala. Konsentrasi minyak pala dilihat dari keberadaan senyawa penyusun ini telah banyak dilaporkan, namun belum sepenuhnya dijelaskan mengenai metabolisme fenilpropanoid melalui jalur shikimat yang dihasilkan dari fenilalanin, diawali kondensasi aldol antara eritrosa 4-fosfat dan asam fosfoenolpiruvat dengan melibatkan reaksi enzimatik dikomparasi dari beberapa tanaman penghasil fenilpropanoid dan Arabidopsis thaliana sebagai tanaman model, yang menjadi tinjauan tulisan ini. Regulasi biosintesis pembentukan senyawa golongan fenilpropanoid menjadi penting karena kita dapat diarahkan pada prospek pengembangan senyawa fenilpropanoid dan turunannya secara lebih luas dengan menghasilkan obat modern bernilai jual tinggi.

Kata kunci: Myristica fragrans Houtt, biosynthesis, phenylpropanoid

\begin{abstract}
Nutmeg (Myristica fragrans Houtt) as a biological bioreactor produces high-value economic essential oils, which are distributed in its fruit parts. Nutmeg essential oil is composed of a large group of terpenoids and phenylpropanoids which have the smallest concentrations but are indicators of the quality of nutmeg oil. The concentration of nutmeg oil from the presence of these compounds has been widely reported but has not been fully explained about the phenylpropanoid metabolism through shikimate pathways produced from phenylpropanoids, preceded by an aldol condensation between 4-phosphate erythrose and phosphoenolpyruvic acid by involving enzymatic reactions compared with phenylpropanoid-producing plants, beginning with aldol condensation between erythrose 4-phosphate and phosphoenolpyruvic acid by involving enzymatic reactions compared with phenylpropanoid-producing plants and precipitating aldol between erythrose 4-phosphate and phosphoenolpyruvic acid by involving enzymatic reactions compared with phenylpropanoid-producing plants. Arabidopsis thaliana as a model plant, which is the review of this paper. The biosynthetic regulation of the formation of phenylpropanoid compounds is important because we can be directed to the prospect of developing phenylpropanoid compounds and their derivatives more broadly by increasing their production or concerning producing high-selling modern drugs.
\end{abstract}




\section{PENDAHULUAN}

Buah pala (Myristica fragrans Houtt) adalah bioreaktor hayati produk-produk bahan alam (Natural Products Bioreactor). Tanaman rempah asal Pulau Banda di Kepulauan Maluku ini telah terkenal mendunia selama berabad-abad karena senyawa aromatik yang dihasilkannya. Buahnya, selain mengandung senyawa-senyawa umum seperti karbohidrat, protein dan lemak struktura (Tainter dan Grenis, 1993) dan mineral-mineral seperti kalium, potasium, magnesium dan fosfor (Al-Bataina et al. 2003), terutama karena minyak asiri yang dikandungnya bernilai ekonomis tinggi.

Sebagai "Bioreaktor Hayati" semua bagian buah pala dapat menghasilkan minyak asiri dengan konsentrasi yang berbeda. Daging buah pala dapat menghasilkan rata-rata $7 \%$, biji $16 \%$, dan dari fuli $15.30 \%$ minyak asiri (Gopalakrishnan, 1992). Minyak asiri pala umumnya dihasilkan dengan penyulingan uap dan ekstraksi superkritis, serta memiliki sifat yang tergantung pada umur buah, cuaca, iklim dan tempat tumbuh (Guenther, 1952; Gopalakrishnan, 1992; Agusta, 2000).

Minyak asiri bukanlah senyawa tunggal, tetapi tersusun dari beberapa komponen yang secara garis besar terdiri dari kelompok terpenoid dan fenilpropanoid, berdasarkan awal terjadinya minyak asiri dalam tanaman. Fenilpropanoid merupakan suatu kelompok penting dari metabolit sekunder tanaman dengan kerangka dasar terdiri dari cincin benzen (C6) yang terikat pada rantai samping propanoid (C3).

Fenilpropanoid diperlukan tanaman sebagai mekanisme pertahanan terhadap cekaman lingkungan biotik maupun abiotik dan bertugas sebagai pengatur berbagai proses fisiologis, seperti pigmentasi bunga dan buah, penyebaran benih melalui penyerbukan, transportasi auksin dan perlindungan UV B (Peer and Murphy, 2007; Tanaka et al., 2008; Agati dan Tattini, 2010; Vogt, 2010). Senyawa ini penting bagi manusia karena memiliki aktivitas farmakologi, berperan dalam industri makanan dan minuman, sebagai bahan baku industri parfum, kosmetik dan aromaterapi (Jaiswal et al., 2009; Maorong et al., 2013).

Golongan fenilpropanoid yang terdapat pada minyak asiri pala diantaranya miristisin, elemisin, safrol, eugenol, metil eugenol, dan trans-metil isoeugenol memiliki konsentrasi terendah bila dibandingkan dengan golongan senyawa monoterpen dan sesquiterpen dalam minyak asiri pala (Mallavarapu dan Ramesh, 1998; Leela, 2008).

\section{PEMBAHASAN}

\section{Komponen Senyawa Minyak Asiri Fenilpropanoid}

Miristisin (4-methoxy-6-prop-2-enyl-1, 3benzodioxole; 1-Allyl-3, 4-methylenedioxy-5methoxybenzene) memiliki nomor registrasi CAS dari American Chemical Society, yakni 607-91-0 merupakan senyawa utama dalam minyak asiri yang menentukan mutu minyak. Miristisin termasuk ke dalam kelompok alilfenol golongan fenilpropanoid.

Konsentrasi miristisin dalam minyak pala bervariasi tergantung asal buah, teknik ekstraksi, dan bagian buah yang digunakan. Analisis konsentrasi miristisin dengan metode ekstraksi superkritis menggunakan $\mathrm{CO}_{2}$ dan destilasi uap dari minyak pala East Indian dan West Indian diperoleh 17,5-25,9\% dan 2,8-3,7\% sedangkan minyak fuli 19,1-24,6\% dan 4,4-9,1\% (Ehlers et al., 1998). Penelitian Maya et al. (2004) melaporkan jumlah miristisin pada minyak pala dan fuli India masing masing $45 \%$ dan $36 \%$. Sedangkan pada daging buah pala menggunakan destilasi air dan destilasi uap diperoleh kadar miristisin $17,4 \%$ dan $11,9 \%$, buah pala yang digunakan berasal dari Maluku Tengah (Sipahelut dan Ivonne, 2011). Selain itu dengan menggunakan metode destilasi uap pada bagian daging buah, fuli dan biji diperoleh kadar miristisin berturut-turut 10,54\%, 38,45\%, 9,24\%, pala yang digunakan dari Cigalontang Tasikmalaya (Ansory et al., 2015).

Keberadaan miristisin dalam minyak pala bersifat racun, mudah terabsorbsi pada konstituen 
lain, miristisin juga dilaporkan sebagai agen yang bersifat halusinogen dan toksik yang dapat menyebabkan keracunan bila dosis berlebihan (Nichols, 2004). Namun menurut Wallis (1960) miristisin memiliki kemampuan dalam mencegah terjadinya keracunan hati oleh karbon tetraklorida pada tikus. Miristsin juga dilaporkan sebagai agen antimikroba, antioksidan, antidepresan, antidiabetes, antiinflamasi dan hepatoprotektor (Dorman \& Deans, 2000; Olajide et al., 2000; Morita et al., 2003). Inilah yang menambah keunikan pada miristisin.

Elemisin

(1,2,3-trimethoxy-5-prop-2enylbenzene; 5-Allyl-1,2,3-trimethoxybenzene) memiliki nomor registrasi CAS dari American Chemical Society, yakni 487-11-6 merupakan komponen minyak asiri pala golongan fenilpropanoid dengan konsentrasi bervariasi berdasarkan asal tempat buah pala dan teknik isolasi yang digunakan. Lewis (1984) melihat konsentrasi berdasarkan daerah asal diperoleh konsentrasi elemisin tertinggi berasal dari Penang 4,6\%, Grenada 1.,\%, Indonesia 0,5\%, Papua 0,4\% dan Singapura 0,3\%. Mallavarapu dan Ramesh (1998) melaporkan konsentrasi minyak asiri pala dan fuli yaitu $2,4 \%$ dan $10,5 \%$. Elemisin memberikan efek halusigenik dan meragsang tidur bersama dengan miristisin (Weiss, 1997).

Safrol (5-(2-Propenyl)-1,3-benzodioxole; 4allyl-1,2-methylenedioxybenzene), nomor registrasi CAS dari American Chemical Society, yakni 94-59-7 dan nomor FEMA [The Flavor and Extract Menufacturers Association (US)] 3010 juga merupakan senyawa golongan fenilpropanoid sebagai identitas dari minyak pala. Analisis komposisi senyawa ini oleh Mallavarapu dan Ramesh (1998) dengan menggunakan ekstraksi biji dan fuli kering melaporkan konsentrasi safrol pada minyak pala dan fuli berturut turut $2,8 \%$ dan $0,7 \%$, dan menggunakan destilasi uap dilaporkan konsentrasi minyak pala dan minyak fuli berkisar antara $2,5-3,7 \%$ dan konsentrasi tertinggi ada pada minyak fuli Papua berkisar 20,5-30,7\% (Ehlers et al., 1998).

Safrol dilaporkan sebagai senyawa yang paling beracun dari golongan fenilpropanoid karena aktivitas karsinogeniknya dan sebagai prekursor untuk MDA, MDEA dan MDMA (ecstacy). Namun berperan dalam sintesis botoksida insektisida piperonil dan digunakan secara luas dalam bidang farmasi dan pasta gigi (Eisner, 1994; Sastrohamidjojo, 2005). Sintesis safrol telah dipelajari selama bertahun tahun, senyawa ini bila direaksikan dengan basa mengalami isomerisasi menjadi isosafrol yang dapat dikonversi menjadi piperonal dengan dioksidasi. Piperonal disebut juga heliotropin berwujud cairan tak berwarna yang memiliki bau harum. Piperonal banyak digunakan sebagai bahan/komposisi pewangi. Reaksi konversi safrol akan menghasilkan safril keton yang juga menjadi turunan L-DOPA (L-3,4dihydroxyphenylalanine) bahan psikoaktif dalam pengobatan Parkinson. Selain itu, Weiss (1997) menyebutkan bahwa senyawa safrol bersifat merangsang tidur berkhayal (halusigenik) dengan dosis kurang dari $5 \mathrm{~g}$. Menurut Triantoro dan Susanti (2007), safrol tidak hanya terdapat pada tanaman pala, tapi juga terdapat pada tanaman kulilawang (Cinnamomum culilawane Bl) dan masoi (Cryptocaria massoia).

Eugenol (4-Allyl-2-Methoxyphenol/ 4-Allyl Guaiacol) memiliki nomor registrasi CAS dari American Chemical Society, yakni 97-53-0 dan nomor FEMA [The Flavor and Extract Menufacturers Association (US)] 2467 merupakan salah satu senyawa fenilpropanoid. Konsentrasi eugenol pada minyak asiri dari biji, fuli, daging buah, bunga dan daun berturut turut $0,4 \%, 0,1 \%, 0,1 \%, 0,71 \%$ dan $0,10-2,16 \%$ (Mallavarapu and Ramesh, 1998; Choo et al., 1999; Leela, 2008).

Keberadaan eugenol sebagai agen penting pembentukan sejumlah senyawa aromatik seperti vanillin; pembuatan obat analgesik lokal dan antiseptik, serta dapat dikonversi menjadi senyawa turunan amfetamin maupun L-DOPA (L-3,4-dihydroxyphenylalanine) yang dikenal sebagai obat Parkinson (Cotzias et al., 1996). Senyawa ini pun banyak digunakan sebagai bahan dasar industri kimia khususnya flavor dan fragrans, farmasi, semen gigi, bahan aktif kemasan makanan, pakan temak, serta aplikasi 
dalam dunia pertanian seperti atraktan untuk lalat buah dan juga obat bius sementara dalam penangkapan dan transportasi ikan (Iwan et al., 2015).

Metil eugenol (Eugenyl methyl ether; 4-allyl1,2-dimethoxybenzene), nomor registrasi CAS dari American Chemical Society, yakni 93-15-2 merupakan senyawa turunan eugenol yang tersubstitusi gugus metil di gugus fenolnya, senyawa ini terkandung dalam minyak asiri biji pala $1,6 \%$, fuli $3,7 \%$, daging buah $0,1 \%$, bunga $0,58 \%$ dan daun berkisar 0,17-0,48\% (Mallavarapu and Ramesh, 1998; Choo et al., 1999; Leela, 2008).

Metil eugenol dikenal sebagai paraferomon serangga atau atraktan lalat buah jantan (Metcalf et al., 1975; Tan dan Nishida, 2012). Senyawa ini banyak terkandung di dalam tumbuhan dan paling umum diproduksi terkait dengan manfaatnya pada tumbuhan sebagai feromon. Namun bagi manusia dicurigai bersifat karsinogenik sehingga penggunaannya dalam indutri makanan di perketat oleh WHO berdasarkan percobaan olleh IARC (International Agency for Research on Cancer).

Penelitian tentang komponen senyawa dengan konsentrasinya pada pala, minyak pala dan minyak fuli telah banyak dilakukan dikarenakan pemanfaatannya dalam bidang farmakologi (Purseglove et al., 1981; Suprihatin et al., 2002; Jaiswal et al., 2009; Adjene et al., 2010; Asgarpanah et al., 2012), bahan baku industri kosmetik dan industri makanan serta minuman (Abdullah et al., 2010; Kapelle dan Marsela, 2010), untuk karakteristik morfoekotipe dan analisis proksimatpun sudah dilakukan (Ilyas et al., 2008), sedangkan jalur pembentukan senyawa-senyawa ini belum sepenuhnya dijelaskan hingga sekarang, studi intensif mengenai biosintesis senyawa golongan fenilpropanoid dan kontrol genetik melalui lintasan shikimat telah dilakukan pada tanaman model Arabidopsis thaliana (Vogt, 2010). Studi ini masih sangat langka, karena belum sepenuhnya dijelaskan pada semua tumbuhan tingkat tinggi termasuk pala sebagai bioreaktor hayati senyawa golongan fenilpropanoid yang merupakan fokus pembahasan paper ini.

Keberadaan senyawa-senyawa pembentuk minyak asiri dari golongan fenilpropanoid pada bagian-bagian buah pala menjadi tolak ukur awal mengapa kami tertarik untuk menulis buah pala sebagai bioreaktor dalam pembentukan senyawa fenilpropanoid yang merupakan konstituen utama sekaligus penentu kualitas minyak asiri pala. Selain itu aspek keberadaan pala di Indonesia sebagai pusat asal usul (Center of Origin), tentu memiliki sumber daya genetik terbanyak. Telah dilaporkan bahwa keragaman tertinggi ada di kepulauan Maluku diantaranya di Pulau Banda, Siau, Sangihe, Ternate, Ambon dan Papua (Heyne, 1927; Hadad dan Hamid, 1990; Hadad, 1992; Peter, 2001; Arrijani, 2005; Anandaraj et al., 2005; Balitro, 2015). Dimana terdapat delapan jenis pala Indonesia yaitu Myristica fragrans Houtt, Myristica argentea Warb, Myristica succedanea Reinw, Myristica speciosa Warb, Myristica schefferi Warb, Myristica fatua Houtt, Myristica tingens Blume, Myristica sylvestris Houtt (Hadad dan Hamid, 1990; Anandaraj et al., 2005; Balitro, 2015). Salah satu jenis pala yang juga terkenal adalah Myristica malabarica Lam. yang berasal dari India.

\section{Biosintesis Senyawa Fenilpropanoid}

Fenilpropanoid merupakan suatu kelompok penting dari metabolit sekunder tanaman dengan kerangka dasarnya terdiri dari cincin benzen (C6) yang terikat pada rantai samping propanoid (C3). Beberapa jenis senyawa yang termasuk fenilpropanoid ialah turunan asam sinamat, turunan alilfenol, turunan propenil fenol dan turunan kumarin. Biosintesis dan fungsi fenilpropanoid telah dipelajari secara intensif di banyak spesies, namun belum sepenuhnya dipahami. Sebagian besar biosintesis ini berasal dari studi biokimia dan genetik pada tanaman model Arabidopsis thaliana (Vogt, 2010). Fenilpropanoid diperlukan tanaman sebagai mekanisme pertahanan terhadap cekaman lingkungan baik itu abiotik maupun biotik, dan bertugas sebagai pengatur berbagai proses fisiologis, seperti pigmentasi bunga dan buah- 
buahan, penyebaran benih melalui penyerbukan, transportasi auksin dan perlindungan UV B (Peer dan Murphy, 2007; Tanaka et al., 2008; Agati dan Tattini, 2010; Vogt, 2010; Dudareva et al., 2013). Fenilpropanoid juga merupakan senyawa yang penting bagi manusia, karena memiliki aktifitas farmakologi luas, industri makanan, minuman, sebagai bahan parfum, kosmetik dan aromaterapi.

\section{Alur Biosintesis Umum}

Biosintesis senyawa fenilpropanoid mengikuti jalur shikimat, yang dihasilkan dari L-Fenilalanin (Phenylalanine/ Phe). Alur biosintesis ini diawali dengan kondensasi aldol antara eritrosa 4-fosfat (E4P) dan asam fosfoenolpiruvat (PEP) dari jalur pentosa fosfat (Herrmann, 1995; Herrmann dan Weaver, 1999; Tzin dan Galili, 2010). Konversi ini melibatkan tujuh reaksi enzimatik dan tiga dari jalur arogenate menghubungkan metabolisme karbon pusat Phe (Tzin dan Galili, 2010; Maeda dan Dudareva, 2012) yang dikatalisis oleh enam enzim.

Enzim pertama dari jalur shikimateadalah 3deoxydsynthase arabino-heptulosonate-7-fosfat sintase (DAHPS) mengkonversi PEP dan E4-P menjadi 3 dehydroquaianate, Tanaman Arabidopsis memiliki dua DAHPS gen yang diketahui yaitu AtDAHPS1 (At4g39980) dan AtDAHPS2 (At4g33510). Ekspresi AtDAHPS1 di Escherichia coli menunjukkan bahwa enzim ini membutuhkan $\mathrm{Mn}^{2+}$ dan mengurangi thioredoxin (TRX) dengan menghubungkan karbon ke jalur shikimate agar elektron mengalir dari fotosistem I (Entus et al., 2002). Aktifitas DAHPS belum diketahui secara pasti kemampuannya sebagai regulator fluks karbon antara metabolisme primer dan sekunder pada tanaman (Maeda dan Dudareva, 2012).

Enzim kedua dari jalur shikimate adalah 3dehydroquinate synthase (DHQS; EC 4.2.3.4; At5g66120), yang mengubah 3-deoksi-darabino-heptulosonate-7-fosfat menjadi 3dehydroquinate. Enzim ini sudah di purifikasi namun fragmen pengkodean cDNA enzim ini belum diisolasi dari tumbuhan tingkat tinggi, dan merupakan satu-satunya enzim tumbuhan dari jalur shikimat yang data strukturalnya belum tersedia.

Enzim ketiga dan keempat adalah enzim katalis bifungsional enzim 3-dehydroquinate dehidratase/shikimate-5-dehidrogenase

(DHQ/SDH) / (At3g06350), yang mengarah ke pembentukan shikimat. Enzim bifungsional ini telah ditandai dalam tomat (Solanum lycopersicum) (Bischoff et al., 2001) dan tembakau (Nicotiana tabacum) (Bonner dan Jensen, 1994). Sebuah studi menunjukkan bahwa gen Arabidopsis AtDHQ / SDH diperlukan untuk pengembangan gametofit betina, dan menjadi satu satunya pada Arabidopsis sedangkan pada tembakau terdapat dua gen yaitu SDH-1 dan $N t \mathrm{DHQ} / \mathrm{SDH}-2$ stabil dengan substrat dehydoquinat dan shikimat (Pagnussat et al., 2005; Ding et al., 2007).

Enzim kelima adalah enzim Shikimate kinase (SK; EC 2.7.1.71), enzim ini mengubah Shikimat menjadi shikimat 3-phosphat. Tanaman Arabidopsis memiliki dua SK isoform: AtSK1 (At2g21940) dan AtSK2 (At4g39540) (Fucile et al., 2008).

Enzim keenam dari jalur shikimat adalah 5enolpyruvylshikimate 3-fosfatsynthase (EPSPS), yang mengarah ke sintesis 5-enolpyruvylshikimat 3-fosfat (EPSP). Akhir dari jalur shikimat yaitu korismat yang menjadi prekursor untuk sintesis asam amino aromatik (AAA) dikatalis oleh enzim chorismate sintase (CS) (Tzin dan Galili, 2010).

Korismat merupakan titik pusat awal pembentukan berbagai senyawa aromatik ini dikatalisis oleh Chorismate mutase (CM; EC 5.4.99.5) yang mengkonversi korismat menjadi prefenat, selain itu korismat ini juga diubah menjadi astralinat dan triptofan yang sebagian besarnya merupakan senyawa nonaromatik. Prefenat ini kemudian diubah menjadi senyawa aromatik. Jalur utama konversi korismat melalui prefenat dan arogenat dikatalisis oleh enzim prefenat aminotransferase (PAT; EC 2.6.1.79) dan arogenat dehidratase (ADT; EC 4.2.1.49) (Cho et al., 2007; Maeda et al., 2010). Namun ada juga jalur lain pembentukan fenilalanin yang dilaporkan melibatkan enzim prefenat 
dedyhratase (PDT) dan prefenat dehydrogenase (PDH) melalui fenilpiruvat, jalur ini digunakan oleh E. coli dan berbagai mikroorganisme lain. Aktivitas enzim prefenat aminotransferase (PAT; EC 2.6.1.79) untuk mengkonversi prefenat ke arogenat pada tumbuhan sudah dilaporkan, namun gen yang mengkode aktivitas enzim ini belum diketahui (Cho et al., 2007). Sedangkan konversi melalui arogenat dengan enzim ADT dilaporkan terdapat enam gen pada Arabidopsis yaitu ADT1 (At1g11790), ADT2 (At3g07630), ADT3 (At2g27820), ADT4 (At3g44720), ADT5 (At5g22630), ADT6 (At1g08250) yang semuanya memiliki aktivitas mengubah arogenat menjadi fenilalanin dilihat dari karakter biokimia rekombinan enzim, dan tiga diantaranya (ADT1, ADT2 dan ADT6) dilaporkan mampu memanfaatkan prefenat sebagai substrat untuk mengubah menjadi fenilpiruvat meskipun aktivitas lebih untuk arogenat (Cho et al., 2007). Sedangkan pada petunia hybrid terdapat tiga gen yang mengkode enzim ADT (Maeda and Dudareva 2012), menggunakan arogenat sebagai substrat dibandingkan fenilpiruvat. Sehingga diduga fenilalanin lebih banyak dihasilkan melalui arogenat sebagai jalur utama (Watanabe et al., 2002; Kaminaga et al., 2006)

Selain fenilalanin (Phe) terdapat dua jenis asam amino aromatik yaitu tirosin (Tyr) dan triptofan (Trp) yang menjadi molekul utama metabolisme senyawa aromatik, (Phe) dan (Tyr) merupakan prekursor awal bagi lignin dan kelompok flavonoid sedangkan (Trp) prekursor bagi kelompok alkaloid. Selain itu asam amino aromatik ini juga sebagai prekursor hormon tanaman seperti auksin dan salisilat.

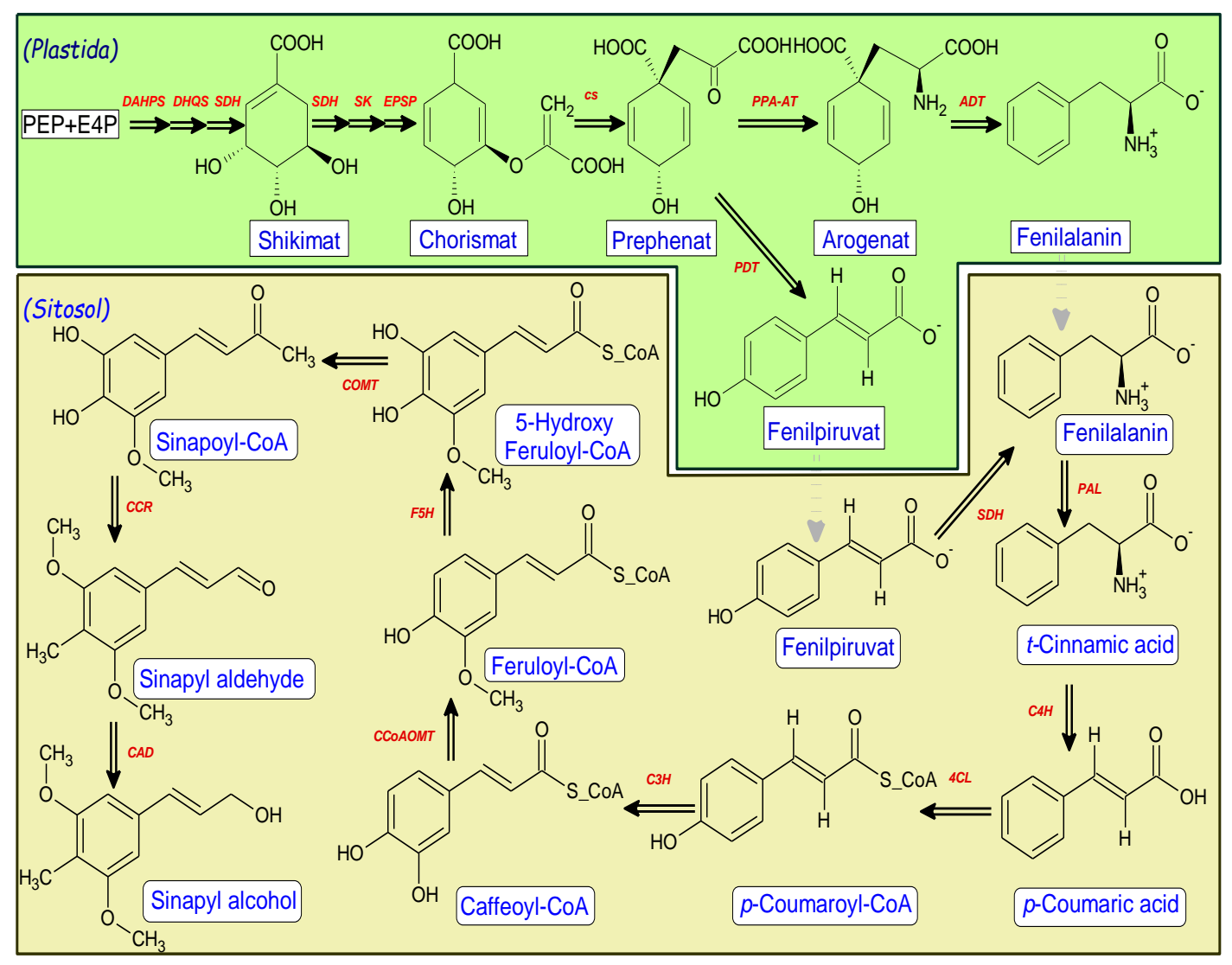

Gambar 1. Alur Biosintesis Umum

Fenilalanin inilah prekursor awal metabolisme fenilpropanoid pada umumnya, dengan mengalami deaminasi menghasilkan asam sinamat trans ( $t$-cinnamic acid) yang dikatalisis oleh enzim Phenylalanine Ammonia Lyase (PAL; EC 4.3.1.5), enzim ini ditemukan pada banyak tanaman, lumut, ganggang, jamur dan juga bakteri. Pada tanaman model Arabidopsis enzim 
ini dikodekan sebagai keluarga gen yaitu PAL1, PAL2, PAL3, PAL4 (Raes et al., 2003), namun tidak keempatnya berfungsi sebagai gen penyandi, hanya PAL1 dan PAL2 yang berfungsi sebagai enzim utama di Arabidopsis (Huang et al., 2010). Analisis kinetik protein yang dikodekan pada keluarga gen PAL, menunjukkan bahwa PAL 1, 2 dan 4 mampu mengkatalis deaminasi fenilalanin secara in vitro, sedangkan PAL 3 tidak begitu berperan aktif (Cochrane et al., 2004).

Reaksi selanjutnya cincin aromatik asam sinamat trans ( $t$-cinnamic acid) dihidroksilasi oleh enzim Cinnamate 4-hydroxylase $(\mathrm{C} 4 \mathrm{H}$; EC 1.14.13.11) untuk menghasilkan 4-coumaric acid ( $P$-Coumaric acid). C4H ini merupakan sitokrom P450 monooksegenase spesifik petama dari tiga sitokrom P450 yang aktif dalam biosintesis lignin. 4-coumaric acid ( $P$-Coumaric acid) kemudian diligasi ke koenzim $\mathrm{A}$, reaksi ini membutuhkan 2 ATP yang ekivalen menghasilkan $p$-Coumaroyl-CoA inilah titik cabang dalam sintesis dan fenilpropanoid dan senyawa metabolit sekunder lainnya seperti fenilpropen, coumarin, lignin, dan lignan (Hamberger, 2007; Vogt, 2010). Penelitian awal pada Arabidopsis untuk mengidentifikasi 4CL sebagai protein tunggal dan dilabeli 4CL 1 (Lee et al., 1995) dan analisis awal menunjukkan protein ini terekspresi dengan endapan lignin di bibit dan batang tanaman dewasa. $p$-Coumaroyl-CoA kemudian dikatalisis oleh enzim Coumaroyl 3hydroxylase $(\mathrm{C} 3 \mathrm{H} ; \quad \mathrm{EC}$ 1.14.13.36) untuk menghasilkan Caffeoyl-CoA. Inilah Sitokrom P450 kedua yang teridentifikasi dalam biosintesis lignin. Pada Arabidopsis teridentifikasi dalam biosintesis lignin (Koeduka et al., 2008) dan juga studi lain yang menunjukkan bahwa enzim ini pun mampu mensintesis metabolit khusus yang terjadi selama perkembangan serbuk sari dan bukan pada lignin saja (Matsuno et al., 2009).

Dalam metabolisme fenilpropanoid Coffeoyl CoA3-O-Methyltransferase (CCoAOMT; EC 2.1.1.104) mengkatalis reaksi metil transfer pertama, dengan sintesis feruloyl-CoA dari Caffeoyl-CoA. Pada Arabidopsis genom terdapat tujuh gen seperti CCoAOMT (Raes et al., 2003) tetapi hanya satu gen yang dikonfirmasi yaitu CCoAOMT1.

Reaksi selanjutnya untuk reaksi ini yaitu Feruloyl-CoA dikatalis oleh enzim Ferulate 5Hydroxylase (F5H) dan menghasilkan 5-Hydroxy Feruloyl-CoA. Enzim ini merupakan sitokrom P450 ketiga yang terdapat pada metabolis fenilpropanoid secara keseluruhan. F5H ini terekspresi secara berlebihan pada Arabidopsis dan tembakau sehingga dianggap sebagai dasar metabolis untuk biosintesis lignin dan metabolit sekunder lainnya (Meyer et al., 1998; Frangke et al., 2000). 5-Hydroxy Feruloyl-CoA kemudian dikatalis oleh Caffeic acid O-methyltransferase (COMT; EC 2.1.1.68) yang kemudian menghasilkan Sinapoyl yang diligasi CoA, kemudian dikatalis oleh Cinnamyl alcohol dedydrogenase (CAD; EC 1.1.1.195) yang merupakan akhir dari biosintesis umum pada metabolit sekunder, dari sinilah akan terbagi monolignol yang berasal dari coniferyl alcohol dan sinaphyl alcohol atau fenilpropanoid dan derivatnya.

\section{SIMPULAN}

Alur biosintesis senyawa fenilpropanoid ini masih harus dipelajari secara mendalam dengan dilakukan penelitian langsung pada buah pala sebagai bioreaktor hayati penghasil minyak asiri yang khas tentunya dengan berpatokan pada Arabidopsis thaliana sebagai tanaman model. Dengan memiliki sumber daya genetik pala terbanyak dan pusat keragamannya berada di kepulauan maluku maka Indonesia sangat diuntungkan dalam menghasilkan sejumlah senyawa penting pada pala dengan lebih baik, banyak dan luas lagi. Selain itu dengan rekaya genetika atau dengan memanipulasi media tumbuh untuk menghasilkan obat baru bagi industri kefarmasian dengan nilai jual tinggi.

\section{UCAPAN TERIMA KASIH}

Terima kasih kepada Departemen Pendidikan Nasional Indonesia yang telah memberikan beasiswa guna melanjutkan studi magister di Universitas Kristen Satya Wacana Salatiga dan 
Sekolah Tinggi Keguruan dan Ilmu Pendidikan Soe yang telah memberikan kesempatan berharga ini.

\section{KEPUSTAKAAN}

Abdullah MHRO, Ch'ng PE, Lim TH. 2010. Determination of some physical properties of nutmeg (Myristica fragrans) seeds. Res. J. Appl. Sci. Eng. Technol 2(7): 669-672.

Agati G, and Tattini M. 2010. Multiple functional roles of flavonoids in photoprotection. New Phytol. 186: 786-793.

Adjene JO, Patrick SI. 2010. Effect of Chronic Consumption of Nutmeg on the Stomach of Adult Wistar Rats. Fooyin Jurnal of Health Sciences 2(2):62-65.

Agusta A. 2000. Minyak Atsiri Tumbuhan Tropika Indonesia. ITB, Bandung.

Arrijani. 2005. Biologi dan konservasi marga myristica di Indonesia. Jurnal Biodiversitas UNIMA 6 (2):147-151.

Al-Bataina, BA, Maslat, AO, Al-Kofahi MM. 2003. Element analysis and biological studies on ten oriental spices using XRF and Ames test. Joumal of Trace Elements in Medicine and Biology 17(2): 85-90.

Anandaraj M, Devasahayam S, Zachariah TJ, Krishnamoorthy B, Mathew PA, Rema J. 2005. Nutmeg (Extension Pamphlet). Publisher V.A. Parthasarathy, Director, Indian Institute of Spices Research.

Ansory HM, Hardjono S, Bambang P. 2015. Comparison of essential oils quality from parts of nutmeg based on myristicin level. Jurnal Farmasi Indonesia 12(2): 127-136.

Asgarpanah J, Kazemivash N. 2012. Phytochemistry and pharmacologica properties of Myrstica fragrans Houtt: a review. African Journal of Biotechnology 11(65): 12787-12793.

Balai Penelitian Tanaman Rempah dan Obat (Balittro). 2015. Buletin Penelitian Tanaman Rempah dan Obat 26(1).
Bonner CA, Jensen RA. Cloning of a cDNA encoding the bifunctional dehydroquinaseshikimate dehydrogenase of aromatic-aminoacid biosynthesis in Nicotiana tabacum. 1994. Biochem J 302:11-14.

Cho JY, Choi GJ, Son SW, Jang KS, Lim HK, Lee SO, Sung ND, Cho KY, Kim JC. 2007. Isolation and antifungal activity of lignans from Myristica fragrans against various plant pathogenic fungi. Pest Management Science 63 (9): 935-940.

Choo LC, Siew MW, Kong YL. 1999. Essential oil of nutmeg pericarp. J Sci Food Agric 79:1954-1957.

Cochrane FC, Davin LB, Lewis NG. 2004. The Arabidopsis phenylalanine ammonia lyase gene family: kinetic characterization of the four PAL isoforms. Phytochemistry 65:15571564.

Cotzias GC, Papavasiliou PS, Gellebe R. 1996. Modification of Parkinsonism-chronic treatmen with L-DOPA. $N$ Engl J Med 290 (7):337-45.

Ding L, Hofius D, Hajirezaei MR, Fernie AR, Bornke F, Sonnewald U. 2007. Functional analysis of the essential bifungctional tobacco enzyme 3-dehydroquinate dehydratase/shikimate dehydrogenase in transgenic tobacco plants. J. Exp. Bot., 58:2053-2967.

Dorman HJ, Deans SG. 2000. Antimicrobial agents from plants: antibacterial activity of plant volatile oils. Journal of Applied Microbiology 88(2):308-16.

Dudareva N, Klempien A, Muhlemann JK, Kaplan I. 2013. Biosynthesis, function and metabolic engineering of plant volatile organic compounds. New Phytol Journal.198 (1):16-32.

Ehlers D, Kirchhoff J, Gerrard D, Quirin KW. 1998. High Performance Liquid Chromatography analysis of Nutmeg and mace oils produced by super critical $\mathrm{CO} 2$ extraction-comparison with steam distiled oils-comparison of East Indian, West Indian and Papuan oils. Intemational Joumal of Food Science and Technology, 33:215-223. 
Entus R, Poling M, Herrmann KM. 2002. Redox regulation of Arabidopsis 3-deoxy-Darabino-heputosonate 7-phospate synthase. Plant Physiol Journal 129:1866-1871.

Eisner B. 1994. Ecstacy, The MDMA Story $2^{\text {nd }}$ Ed. Ronin, Berkeley.

Franke R, McMichael CM, Meyer K, Amber M. Shirley, Joanne C. Cusumano. 2000. Modified Lignin in tobacco and poplar plants over-expressing the Arabidopsis gene encoding 5-hydroxylase. The Plant Journal 22(3): 223-234.

Fucile G, Falconer S, Christendat D. 2008. Evolutionary diversification of plant shikimate kinase gene duplicates. PloS Genet 4: e1000292.

Gopalakrishnan M. 1992. Chemical composition of nutmeg and mace. Joumal of Spices and Aromatic Crops, 1:49-54.

Guenther E. 1952. The Essential Oil Vol II, III, and $V$. Van Nostrand Reinhold Company. New York.

Hadad EA. 1992. Pala. Edisi Khusus Penelitian Tanaman Rempah dan Obat. 8(2): 26-37.

Hadad EA, Hamid A. 1990. Mengenal berbagai plasma nutfah pala di daerah Maluku Utara. Balai Penelitian Tanaman Rempah dan Obat. Bogor.

Hamberger B. 2007. Genome-wide analyses of phenylpropanoid-related genes in Populus trichocarpa, Arabidopsis thaliana and Oryza sativa: the populus lignin toolbox and conservation and diversification of angiosperm gene families. Journal Botany 85: 1182-1201.

Herrman KM. 1995. The Shikimate Pathway: early steps in the biosynthesis of aromatic compounds. Plant cell 7: 907-919.

Herrman KM. 1995. The Shikimate Pathway as an entry to aromatic secondary metabolism. Plant Physiol 107: 7-12

Herrman KM, Weaver LM. 1999. The shikimate pathway. Annu. Rev. Plant Physiol. Plant Mol. Biol 50: 473-503.
Heyne, K. 1927. De Nuttings Planten Van Nedelandesh Indish. Ruygrok and Cp. Batavia. 196.

Huang JL, Gu M, Lai ZB, Fan BF, Shi K, Zhou YH, Yu JQ, Chen ZX. 2010. Functional analysis of the arabidopsis PAL gene family in plant growth, development, and response to environmental stress. Plant Physiol 153: 1526-1538.

Ilyas M, Uluputty MR, Sandra AA, Memen Surahman. 2008. Karakteristik morfoekotipe dan proksimat pala banda (Myristica fragrans Houtt). Bul. Agron 36(2):146-152.

Iwan S, Askal M, Anton RP. 2015. Effect of crushing of clove bud (Syzygium aromaticum) and distillation rate on main constituents of the essential oil. American Journal of Essential Oils and Natural Products 2(3):12-15.

Jaiswal P, Kumar P, Vinay KS, Dinesh KS. 2009. Biological effects of Myristica fragrans. Annual Review of Bimedical Sciences 11:2129.

Kapelle IBD, Marsela SL. 2014. Trymiristin isolation from nutmeg and synthesis of methylester using heterogen catalyst. J. Ind Chem Res 2: 160-165.

Kaminaga Y, Schnepp J, Peel G, Kish CM, BenNissan G, Weiss D, Orlova I, LAvie O, Rhodes D, Wook K, Porterfield DM, Cooper AJ, Schloss JV, Pichersky E, Vainstein A, Dudareva N. 2006. Plant phenylacetaldehyde synthase is a bifunctional homotetrameric enzyme that catalyzes phenylalanine decarboxylation ands oxidation. J Biol Chem 281(33):23357-23366.

Koeduka T, Gordon VL, Irina O, Christine MK, Mwafag I, Curtis GW, Marianne EB, Thomas JB, Joseph PN, Natalia D, Eran P. 2008. The multiple phenylpropenen synthases in both Clarkia breweri and petunia hybrid represent two distinct protein ineages. Plant J 54(3): 362-374.

Lee D, Ellard M, Wanner LA, Davis KR, Douglas CJ. 1995. The Arabidopsis thaliana 4coumarate: CoA ligase (4CL) gene: stressand developmentally regulated expression and 
nucleotide sequence ofits cDNA. Plant Mol. Biol 28: 871-884.

Leela NK. 2008. Nutmeg and Mace. CABI Intemasional. London, UK bby Biddles Ltd.

Lewis YS. 1984. Spices and Herbs for the Food Industry. Food Trade Press, Oripington, England.

Maeda H, Dudareva N. 2012. The shikimate pathway and aromatic amino acid biosynthesis in plants. Annual review of plant biology 63:73-105.

Mallavarapu GR, and Ramesh S. 1998. Composition of essential oils of nutmeg and mace. J. Medicinal and Aromatic Plant Sciences 20(3):746-748.

Maorong S, Tomihisa $\mathrm{O}$, Fumihide $\mathrm{T}$, and Shouwen J. 2013. Bioactive phenylpropanoid glycosides from Tabebuia avellanedae. Molecules 18(7):7366-7345.

Maya KM, Zachariah J, Krishnamurthy T. 2004. Chemical composition of essential oil of nutmeg (Myristica fragrans Houtt) accessions. Journal Spices and Aromatic Crops 13 (2): 135-139.

Matsuno M, Compagnon V, Schoch GA, Schmitt M, Debayle D, Bassard JE, Pollet B, Hehn A, Heintz D, Ullmann P, Lapierre C, Bernier F, Ehlting J, Werck, Reichhart D. 2009. Evolution of a novel phenolic pathway for pollen development. Science 325: 16881692.

Metcalf RL, Mitchell WC, Futuko TR, Mercalf ER. 1975. Attraction of the oriental fruit fly, Dacus dorsalis, to methyl eugenol and related olfactory stimulants. PNAS 72(7):2501-2505.

Meyer K, Shirley AM, Cusumano JC, BellLelong DA, Chapple C. 1998. Lignin monomer composition is determined by the expression of a cytochrome P450-dependent monooxygenase in Arabidopsis. PNAS 95: 6619-6623.

Morita T, Jinno K, Kawagishi H, Arimoto Y, Suganuma H, Inakuma, Sugiyama K. 2003. Hepatoprotective effect of myristicin from nutmeg (Myristica fragrans) on lipopolysaccharide/d-galactosamine-induced liver injury. Journal of agricultural and food chemistry 51(6):1560-1565.

Nichols DE. 2004. Hallucinogen. Journal Pharmacology and Therapeutics. 101:131181.

Olajide OA, Makinde JM, Awe SO. 2000. Evaluation of the pharmacological properties of nutmeg oil in rats and mice. Pharmaceut. Biol 38: 385-390.

Pagnussat GC, Yu HJ, Ngo QA, Rajani S, Mayalagu S, Johnson CS, Capron A, Xie LF, Ye D, Sundaresan V. 2005. Genetic and molecular identification of genes required for female gametophyte development and function in Arabidopsis. Development 132: 603-614.

Peer WA, Murphy AS. 2007. Flavonoids and auxin transport: modulator regulator. Trends Plant Sci 12: 556-563.

Peter KV. 2001. Herbs and spices. Woodhead Publishing Limited and CRC Press LLC, Cambridge England. 332p.

Purseglove J, Brown EG, Green SL, Robbins SRJ.1981. Spices. Nutmeg and Mace. Vol I. Longman Inc. New York. 439:174-228.

Raes J, Rohde A, Christensen JH, Van de Peer Y, Boerjan W. 2003. Genome-wide characterization of the lignification toolbox in Arabidopsis. Plant Physiol 133: 10511071.

Sipahelut S, Teluusa I. 2011. Karakteristik minyak atsiri dari daging buah pala melalui beberapa teknologi proses. Jurnal Teknologi Hasil Pertanian 4(2): 126-134.

Sastrohamidjojo H. 2005. Prospek Minyak Atsiri Indonesia. UGM.

Suprihatin, Ketaren S, Nyudiwaluyo S, Friyadi A. 2002. Isolasi miristisin dari minyak pala (Myristica fragrans) dengan metode penyulingan uap. Jurnal Teknologi Industri Pertanian 17(1):23-28.

Tainter RD, Grenis TA. 1993. Spices and seasonings Food Science and Technology. VCH Publishers, New York, P.226. 
Tan KH, Nishida R. 2012. Methyl eugenol: its occurrence, distribution, and role in nature, especially in relation to insect behavior and pollination. Journal of Insect Science 12: $1-74$.

Tanaka Y, Sassaki N, Akemi O. 2008. Biosynthesis of plant pigments: anthocyanins betalains and carotenoids. Plant Journal 54: 733-749.

Triantoro RGN, Susanti CME. 2007. The Chemical Content of Kulilawang (Cinnamomum culilawane B1.) and masoi (Cryptocaria massoia) Wood. Jurnal Ilmu dan Teknologi Kayu Tropis 5(2).

Tzin V, Galili G. 2010. New insights into the shikimate and aromatic amino acid bioshynthesis pathways in plants. Molecular Plant 3(6):956-972.

Vogt, T. 2010. Phenylpropanoid biosynthesis. Molecular Plant 3: 2-20.

Wallis, T. E. 1960. Text Book of Pharmacognosy. $\mathrm{J} \& \mathrm{~A}$ Churchill Ltd. London.

Watanabe S, Kentaro H, Kensuke Y, Tatsuo A, Hazel MT, Joanne P, Colin T, Naoharu W. 2002. Biogenesis of 2-phenylethanol in rose flowers: Incorporation of [2H8] Lphenylalanine into 2-phenylethanol and its $\beta$ D-glucopyranoside during the flower opening of Rosa 'Hoh-Jun' and Rosa damascene Mill. Bioscience Biotechnology and Biochemistry 66(5):943-947.

Weiss EA. 1997. Essential Oil Crops Chapter 7:

Myristicaceae. 